\title{
Correction to: Evolution of multicellularity: cheating done right
}

\section{Walter Veit ${ }^{1}$ (1)}

Published online: 24 December 2019

(C) Springer Nature B.V. 2019

\section{Correction to: Biology \& Philosophy (2019) 34:34 https://doi.org/10.1007/s10539-019-9688-9}

The author would like to notify the readers about the following.

While the research for this article has been undertaken during an internship at the Max Planck Institute, this should have been credited in the acknowledgements section, rather than as a secondary affiliation.

Copyright information about the figures should have been given in the captions, rather than the footnotes. The full copyright information with declared rights is given as follows:

Fig. 1/Page 8: From groups to individuals

Reused with authors' permission, see Peter Godfrey-Smith "Darwinian populations and natural selection”. Oxford University Press, Oxford (2009, p. 95, Fig. 5.1). Reproduced with permission of the Licensor through PLSclear.

Fig. 2/Page 12: Mat formation in Pseudomonas fluorescens

Reused with authors' permission and reprinted by permission from John Wiley and Sons: BioEssays (Cheats as first propagules: "A new hypothesis for the evolution of individuality during the transition from single cells to multicellularity", Paul B. Rainey, Benjamin Kerr), (C) John Wiley and Sons (2010, p. 875, Fig. 2).

Fig. 3/Page 13: Mat life cycle

Reused with authors' permission and reprinted by permission from John Wiley and Sons: BioEssays ("Cheats as first propagules: A new hypothesis for the evolution of individuality during the transition from single cells to multicellularity", Paul B. Rainey, Benjamin Kerr), (C) John Wiley and Sons (2010, p. 876, Fig. 3).

Fig. 4/Page 34: Three causes for extinction

Reused with authors' permission and reprinted by permission from Springer Nature: Nature ("Life cycles, fitness decoupling and the evolution of

The original article can be found online at https://doi.org/10.1007/s10539-019-9688-9.

Walter Veit

wrwveit@gmail.com

1 University of Bristol, Bristol, UK 
multicellularity”, Katrin Hammerschmidt, Caroline J. Rose, Benjamin Kerr, Paul B. Rainey), (C) Springer Nature (2014, p. 76, Fig. 1b).

Fig. 5/Page 34: Cheat-embracing regime trumps cheat-purging regime

Reused with authors' permission and reprinted by permission from Springer Nature: Nature ("Life cycles, fitness decoupling and the evolution of multicellularity”, Katrin Hammerschmidt, Caroline J. Rose, Benjamin Kerr, Paul B. Rainey), (C) Springer Nature (2014, p. 76, Fig. 1a).

Publisher's Note Springer Nature remains neutral with regard to jurisdictional claims in published maps and institutional affiliations. 